\title{
GO-BYAR BASED ON VIRTUAL REALITY FOR THE LEARNING MEDIA OF GAMELAN
}

\author{
Kadek Dwipayana, I Made Agus Wirawan, and I Gede Partha Sindu \\ Universitas Pendidikan Ganesha, Indonesia \\ E-mail: imade.aguswirawan@undiksha.ac.id
}

\begin{abstract}
Gong Kebyar is one of the group of Balinese music that has five pelog tones which the playing technique using kebyar system. Gong Kebyar serves the instrumental performances, accompanying various types of dances, and accompanying Himdu's religious ceremonial activities in Bali. But not many young people can play the gong kebyar due to lack of adequate facilities. One effort that can be done is to utilize virtual reality technology as an instructional media for playing Gong Kebyar. The purpose of the study was to design and implement the design of Gamelan Gong Kebyar based on Virtual Reality. The development of the Gamelan Gong Kebyar Game based on Virtual Reality was implemented using the ADDIE model. The main feature of this game was playing the gamelan Gong Kebyar instrument, besides that there is a feature playing the instrument accompanied by the song so that the player could feel the situation of playing it in form of sekaa. The design is using a functional model which is UML (Unified Modeling Language) and implemented using programming language $\mathrm{C} \#$ which edited by MonoDevelopUnity. The results of this study is a Gong Kebyar application based on virtual reality which is operated with a computer and HTC VIVE VR device. All features in this application function properly. With this application, the community can learn to play Gong Kebyar with the results of the user response test obtaining a value of $91 \%$, which means it is included in the excellent category.
\end{abstract}

Keywords: addie, gong kebyar, instrument, user response, virtual reality

\section{INTRODUCTION}

Bali Island is one of the Indonesian islands that has been known by the world. There are some factors which make Bali become well-known, one of them is culture ad art of Bali. One of the art in Bali which still exist in the art of Gamelan. Gong Kebyar is a gamelan in the form of a group which the pitched using "pelog lima" (five tones) that producing the musical term which called Kebyar. As a gamelan, Gong Kebyar has a function to show the instrumental song to be accompanied by the Balinese dances and Hinduism cultural ceremonial [1]. This is the reason why gamelan Gong Kebyar art has to be preserved.

Based on the interview result, the problems that usually be found in some places of learning about tabuh is the minimum gamelan instructors that can be found on every village so the one who willing to learn about gamelan sometimes need to find the trainer from other places. Then the other problem that usually been found in the instrument condition which less supportive such the less amount of the instrument and the trainer also said some villages do not have gamelan instrument which actually has a very important function on the group of Gong Kebyar. This became a problem for the one who wanted to play gamelan because of the limited number of the existing instruments. This is in a line with the interview survey with 10 university students which come from different districts. $70 \%$ of them stated that the instruments for playing gamelan in their places were less than the number of people who want to learn 
about it. In addition, based on the questionnaire that has been spread out to the teenagers by the researcher, it has gained 43 respondents which the result was $83.7 \%$ of them could not play Gong Kebyar instrument. With that amount of percentage, it seems that the implementation of gamelan Gong Kebyar was very less.

Some Android based applications of gamelan have been developed before. Wardhana et al. [2] developed the instruments of traditional music with making a simulation instrument in the android operation system. This application could facilitate someone in playing Gong Kebyar using their android smartphone. The second research is a research that has been done by Susila [3]. He studied gamelan Selonding Android based development. The background of the study was mostly similar. In this application feature, the player could play Selonding Gamelan on Android smartphones. The third research is a research that has been done by Udiyana et al. [4] who built an application of Android-based Balinese gamelan angklung. The problem from this study was gamelan angklung being left by the teenagers, one of the factors which cause it is technology development. Thus application feature could help them playing Gamelan Angklung by only using smartphones.

However. The existing studies only develop the application to introduce gamelan. For the beginner, an instructor is still needed to engage them in playing Gong Kebyar, besides that the design of those Android-based applications are still in 2 dimensions so the experience that has been gained in this application seems different with the experience playing gamelan in the real life.

It would be interesting and more effective if the technology development which is used to apply this gamelan has to give observation effect and real experience, give a chance for the user to have interaction with the gamelan instrument, it would make the user understand the function of the instrument included there.

Technology development nowadays could finish these problem with Virtual Reality technology. The fast growth and accessibility of low-cost technology has generated a wide interest in virtual reality [5]. Virtual Reality may give the opportunity for the education sector to apply it for efficient teaching and learning [6], [7] , in particular to provide learners with realistic learning experience.

Virtual Reality could make the user have interaction with the environment simulated by the computer [8], [9]. The environment which created can be very similar to the real world because the experience on the virtual world represents by the simulation which combining the senses (visual, audio, touch). Therefore the researcher decided to develop a Virtual Reality-based Gong Kebyar gamelan instrument game. This game is including the introduction of gong kebyar instrument and tutorial of playing that instrument. The tools which used is Virtual Reality high censored tools produced by HTC Vive industry. This is expected that this game assists the global society to play Gong Kebyar gamelan instruments easily and could give a contribution to preservation of Balinese art.

\section{METHOD}

This study used Research and Development (R\&D) method. It is used to produce certain products and to test the effectiveness of the product. This development used the ADDIE model because this model is very useful and has clearly defined stages which makes the implementation effective. It also provides 
simple procedures to design and develop materials [10]. The ADDIE model consists of five steps that consist of analysis, design, development, implementation, evaluation presented in Figure 1 [11].

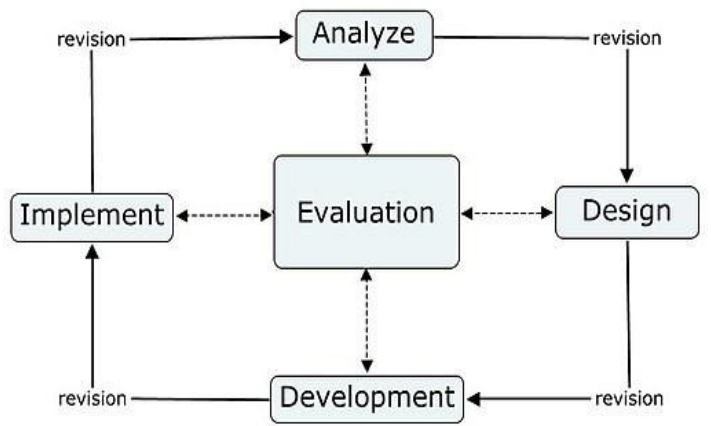

Figure 1. Steps of the ADDIE Model

In the analysis step, the researcher identified the problems that have been found so it can be used as the reference to develop Gamelan Gong Kebyar Virtual Realitybased Game. In this step, the problem analysis and the solution were explained with the functional and non-functional need analysis.

In the design step, the researcher designed an application. The researcher proceeds the design which including the use case diagram for drawing the actor design (the user or another system), use case (description function of a system) and the relation as the action order that giving measurable value for the actor. Then the activity diagram design described some activities plots on the system that still being designed, how the plot started, the expected action and how the plot ended. The third design was interface application design that can be used as a reference for application development.

After the design was completed, it continued with the development step, the framework which still being a concept to be created became a product which would be ready to be implemented. In this step, assets for Go-Byar game were being developed. The assets which were being developed were 3D assets, audio, and pictures. On the development of the 3D asset, the principle which is used is LOD (Level of Detail). LOD (Level of Detail) or detail level is a regular design term for a video game which the closest object is given with more polygon [8]. Then after all of the assets have been developed they would be implemented into the application which modified by the game engine that became the application which ready to be tested.

The test for this application was done using black-box testing that focusing on functional needs of the software. The test was conducted to validate the indicator such as main menu state, game state, tutorial and setting [12]. In addition. To examine whether the received input function was corresponded with the produced output, the white box testing was conducted as the second step of testing the product. This test focused on internal structure data used for ensuring validity from the application [8]. The third testing is of media expert's judgment that focused from interface application test. It involved two lectures as the examiners. The fourth testing was a content judgment which focused on the content of the application especially which was related to gamelan gong kebyar. It was performed by two Balinese art experts in the gamelan field.

The last testing was the user response test. The respondents were the members of an art student's activity unit in Universitas Pendidikan Ganesha, Bali. The number of respondents were 20 students. The students was selected as the respondents because they studied regional arts, especially kebyar gong. Testing was conducted by distributing questionnaires to respondents with 5 
alternative answers to each statement, namely strongly agree, agree, fairly agree, disagree, and strongly disagree. After the results were obtained, the calculation was then performed to find out the percentage of users' responses.

\section{RESULTS AND DISCUSSION}

To be able to implement the application, there are some hardware that should be provided such as personal computer (PC) and HTC VIVE with certain specification [13]. Table 1 presents the minimum hardware requirements.

Table 1. Minimum Hardware Requirements

\begin{tabular}{ll}
\hline Item & Spesification \\
\hline Processor & Intel core i7 \\
OS & Windows 10 \\
Ram & $16 \mathrm{~GB}$ \\
VGA & Nvdia Geforce GTX 1050Ti \\
\hline
\end{tabular}

In order to represent the design to be able to implement as a program on the next step, it was required a diagram. The diagram could describe the problem and the solution. In developing this game, the researcher used the use case diagram. This application designed based on the use case diagram because it could show the system functionality [14]. The result of the use case diagram of the application was illustrated in Figure 2.

From the use case diagram, it was then produced the application which was in line with the application design reference that has been fulfilled the functional needs. Based on the functional needs that has been reached, in order to easily understand the content of the application, it needs to be implemented using the interface of the application. Interface tools or the layout was used for connecting the user with the software for gaining interaction. This application has a simple interface and userfriendly for being easy to operate and understand by the user. Regarding the selection mode on the application menu, this application is using a HTC VIVE controller. Table 2 shows the functional needs and Figure 3 describes the grand design of GoByar.

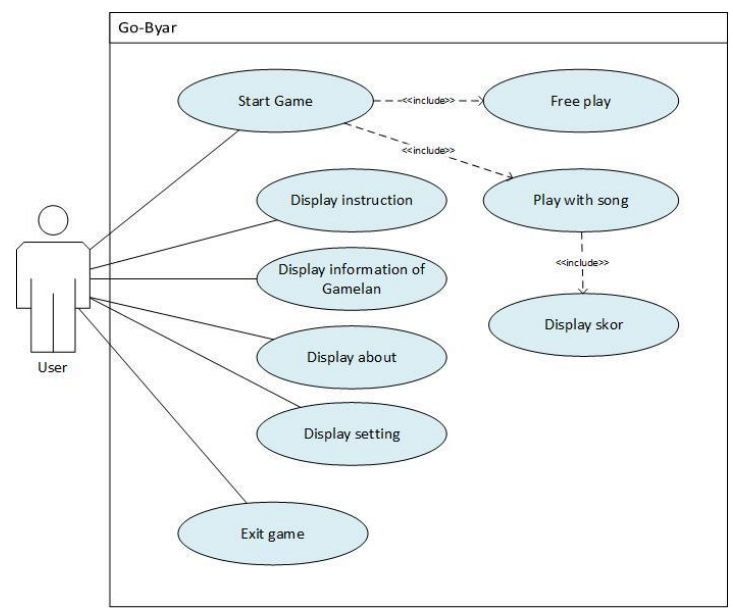

Figure 2. Use Case Diagram

For the main menu, there is a "start selection" for starting to play the game, "instruction" to see the way for playing, "info gamelan" for seeing gamelan information and "exit" to get out from the application. When the user selection is start menu so it would be shown the other selection whether they would like to play as freestyle or play with music. If the user chooses to play freestyle, the player could choose the gamelan instrument that would like to play freely without being accompanied by music or playing rules. Every instrument has a different sound position and beater.

If the player chooses to play with the music menu, the player could play the instrument accompanied by gamelan music and would be some notation of tones from the music which must be followed to gain 
points. If the player hits the tones correctly, the accumulation point would be 100 , if the player only could hit the tones correctly about 5 times, the points will gain combo 2 times and when it turns to be wrong tones the combo point would be disappeared .

Table 2. Functional Needs

\begin{tabular}{|c|c|}
\hline Code & Decription \\
\hline KF-01 & $\begin{array}{l}\text { The application could show the interface } \\
\text { of the main menu including game start, } \\
\text { instruction, gamelan info, setting and exit } \\
\text { game. }\end{array}$ \\
\hline KF-02 & $\begin{array}{l}\text { The application could show up playing } \\
\text { interface freely and playing with the song } \\
\text { when choosing game start. }\end{array}$ \\
\hline KF-03 & $\begin{array}{l}\text { The application could show up the layout } \\
\text { of the interface list of gamelan Gong } \\
\text { Kebyar instruments that have been stored } \\
\text { when choosing freely playing. }\end{array}$ \\
\hline KF-04 & $\begin{array}{l}\text { The application could show up freestyle } \\
\text { playing when choosing one of the } \\
\text { instruments. }\end{array}$ \\
\hline KF-05 & $\begin{array}{l}\text { cation could sound gamelan } \\
\text { hit by the player }\end{array}$ \\
\hline KF-06 & $\begin{array}{l}\text { The application could show up the game } \\
\text { with music when the player chooses to } \\
\text { play with music.. }\end{array}$ \\
\hline KF-07 & $\begin{array}{l}\text { The application could show op game } \\
\text { tutorial. }\end{array}$ \\
\hline KF-08 & The application could show gamelan info. \\
\hline KF-09 & $\begin{array}{l}\text { The application could show the score of } \\
\text { the game when it is done to play with } \\
\text { music. }\end{array}$ \\
\hline KF-10 & $\begin{array}{l}\text { The application could show the } \\
\text { information about application } \\
\text { development }\end{array}$ \\
\hline KF-11 & $\begin{array}{l}\text { The application could show up the } \\
\text { confirmation of selection when the exit } \\
\text { menu is hit. }\end{array}$ \\
\hline KF-12 & $\begin{array}{l}\text { The application could show up volume } \\
\text { adjustment. }\end{array}$ \\
\hline
\end{tabular}

On the instruction menu, there is the information of the way to play the game freestyle, playing with the song, player position setting, using controller, playing software structure and virtual reality calibration's way to be able to use. On the menu of gamelan info, there is a description of every gamelan gong kebyar music, the description including name and notation of every instrument's tones. On the "about" menu there is information from the application, developer information and the credit of application.

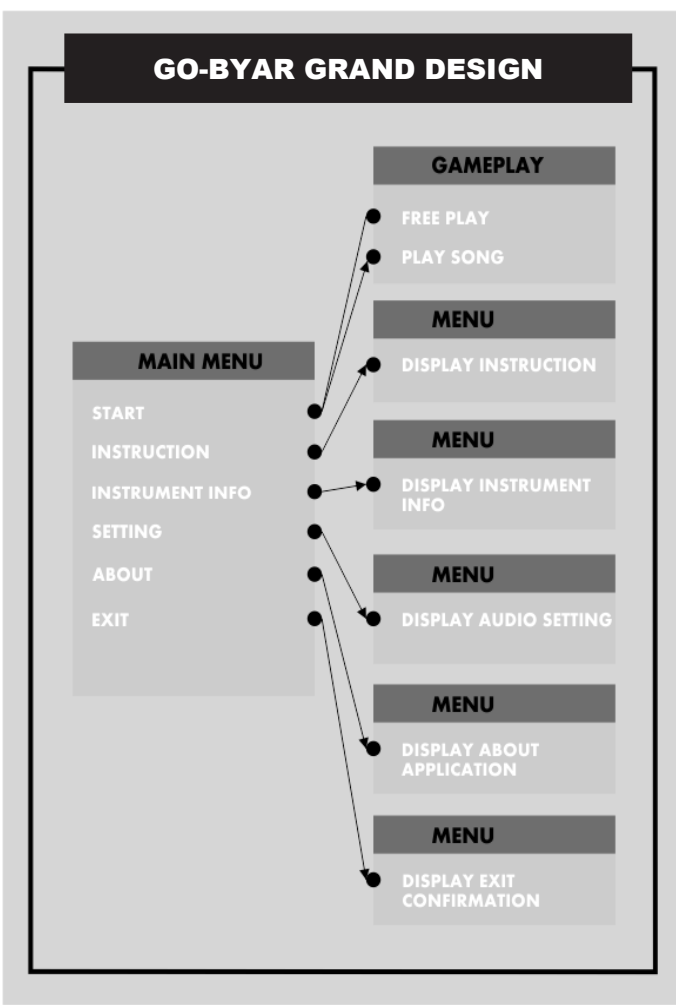

Figure3. The Grand Design of Go-Byar

After passing the playing with music mode, the player could see the score result when playing. The score which is shown would be reset after playing again. In implementing Go-Byar Virtual Realitybased application, there were the orders of hardware used for it applied well. Figure 4 presents the hardware structure which is applied. The first is a computer s used to run the application. The computer should be in connection with virtual reality tools. The second is a base station which the function as the censored to detect player position. This sensor has A and B channels for being connected. On this sensor's order has been put face to face with the range of space about 2 meters on the floors. The third is the 
headset of virtual reality's tools which would be worn by the player. The headset has to connect with the computer and the power to be operated. The fourth is the player position, it is used to make the base station detects the players' position thus it stays on the center and bellow the base station. The fifth is a controller from virtual reality used by the player to input for the application.

Based on the ADDIE research model, the evaluation process would be performed in every last of the step. In the design step, the researcher designed several items such as application menu structure, application content, user interface, and design which would be applied was evaluated. Evaluation in the design step would be focusing on visual design, characters, audio, and interface design [15]. The interface design was evaluated by media experts whose professions were lectures in the Department Informatics Enginerring in Universitas Pendidikan Ganehsa. The result of the media expert evaluation was $100 \%$ corresponding.

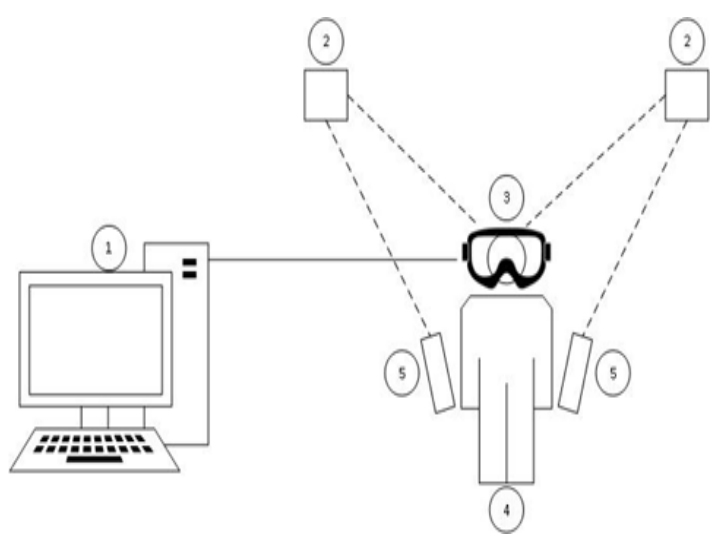

Figure 4. Hardware Implementation Structure

In the evaluation step, the researcher further evaluated the result of the design step. It was the test to evaluate the indicator of experience, the goal of education and learning [16]. This content evaluation was focused on the content and materials judgment from the application, word use, language use, and learning process. The assessor was a tabuh trainer. The researcher combined this assessor with a content expert because it has a relation in the concentration of gong Kebyar gamelan. From those experts, the evaluation result was $100 \%$ corresponding.

In the development step, the researcher has developed every component that has been designed before. The evaluation of this step was focused more on the functional needs of the evaluation result. The examination which had been conducted consisted of two types naley White box testing by the researcher and Black box testing by 5 respondents with the required instrument.

The last step of evaluation was conducted to find the responds of the user after applying the application. The examination was conducted to validate the challenging indicators, interaction, emotional experience, easy to learn [17] to 20 users. They consisted of 15 people from society and 5 students from art student's activity unit. The evaluation results reached $91 \%$ indicated that the developed application categorized as very good.

Based on the theory of computer technology in the real life [18], society response towards the developed application showed that this study was beneficial because it contained the criteria of (1) providing authentically contextual knowledge which would be reflected on the real life, (2) providing a real activity, (3) providing double role using perspective, and (4) supporting the collaborative knowledge.

\section{CONCLUSION}

The development of "Go-Byar" Gong Kebyar based Virtual Reality game used the 
ADDIE model. In the designing steps, it used several application including Unity 3D, Blender 3D, Fl Studio, and CorelDraw. The Unity 3D application was used as engine game which the $\mathrm{c \#}$ as the programming language for making this application. Blender 3D application was used to create $3 \mathrm{D}$ objects that were being the assets of this project with fbx extension for being able to be imported to Unity 3D. In order to do editing, it used F1 studio application that the result can be used as audio assets in the game. Then for creating the icon and editing the picture, it was used CorelDraw application. After the game application was designed, it was examined using white box tesing, black box testing and media and content expert's validation. The Gong kebyar application that has passed the testing phase is then implemented as an instructional media for playing gong kebyar whose target users are the members of art student's activity unit in Universitas Pendidikan Ganesha. The results of the implementation achieved a response with the score of $91 \%$ classified as very good. Based on these results, this application can be used as instructional media to play the gong kebyar.

\section{REFERENCES}

[1] I. W. Suharta and N. K. D. Yulianti, Signifikansi Bahasa Inggris Dalam Proses Belajar-Mengajar Gamelan Gong Kebyar Bagi Mahasiswa Asing dalam Upaya ISI Denpasar Go Internasional, no. April. Denpasar: Institut Seni Indonesia, 2011.

[2] I. P. S. P. Wardhana, I. G. M. Darmawiguna, and I. M. G. Sunarya, "Pengembangan Aplikasi Instrumen Gamelan Gong Kebyar Berbasis Android," J. Nas. Pendidik. Tek. Inform., vol. 4, no. 2, p. 58, Jul. 2015.
[3] I. P. N. Susila, "Pengembangan Aplikasi Gamelan Selonding Berbasis Android," vol. 4, pp. 82-91, 2015.

[4] I. G. E. Udiyana, I. G. M. Darmawiguna, and I. M. G. Sunarya, "Pengembangan Aplikasi Gamelan Angklung Bali Berbasis Android," KARMAPATI (Kumpulan Artik. Mhs. Pendidik. Tek. Inform., vol. 4, no. 4, pp. 248-257, 2015.

[5] S. Serafin, C. Erkut, J. Kojs, N. C. Nilsson, and R. Nordahl, "Virtual Reality Musical Instruments: State of the Art, Design Principles, and Future Directions," Comput. Music $J$., vol. 40, no. 3, pp. 22-40, Sep. 2016.

[6] E. $\mathrm{Hu} \mathrm{Au}$ and J. J. Lee, "Virtual Reality in Education: a Tool for Learning in the Experience Age," Int. J. Innov. Educ., vol. 4, no. 4, p. 215, 2017.

[7] K. K. Omieno, F. Wabwoba, and N. Matoke, "Virtual Reality in Education: Trends and Issue," Int. J. Comput. Technol., vol. 4, no. 1, pp. 38-43, 2013.

[8] R. W. Khoerniawan, I. M. Putrama, and K. Agustini, "Game Edukasi Penjelajah Berbasis Virtual Reality," Kumpul. Artik. Mhs. Pendidik. Tek. Inform., vol. 7, no. 1, p. 20, Feb. 2018.

[9] A. Suryanto, D. A. Kusumawati, and I. M. H. Sanhoury, "Development of Augmented Reality Technology Based Learning Media of Lathe Machines," J. Pendidik. Teknol. dan Kejuru., vol. 24, no. 1, pp. 32-38, 2018.

[10] M. Mardiana and E. Fitriani, "Developing Signs and Songs Materials Dealing with the 2013 Curriculum for the Seventh Grade Students in Mtsn Balang-Balang," Langkawi J. Assoc. Arab. English, vol. 2, no. 2, pp. 187-201, Oct. 2016.

[11] G. Muruganantham, "Developing of E-content Package by Using ADDIE 
Model," Int. J. Appl. Res., vol. 1, no. 3, 2015.

[12] K. Dyrr, P. N. Farias, R. Oliveira, and B. Sparks, Game Development for Human Beings. Zenva Academy, 2016.

[13] M. A. Pranata, G. S. Santyadiputra, and I. G. P. Sindu, "Rancangan Game Balinese Fruit Shooter Berbasis Virtual Reality Sebagai Media Pembelajaran," Janapati, vol. 6, pp. 256-270, 2017.

[14] S. R. Schach, Classical Software Engineering, 8th ed. New York: McGraw-Hill, 2007.
[15] J. Schell, The Art of Game Design. Burlington: Morgan Kaufmann, 2008.

[16] D. Moursund, Introduction to Using Games in Education: A Guide for Teachers and Parents, vol. 6. 2007.

[17] R. Rouse, Game Design: Theory and Practice, 2nd ed. Jones \& Bartlett Learning, 2005.

[18] H. H. Mei and L. ShuSheng, "Applying Situated Learning in a Virtual Reality System to Enhance Learning Motivation," Int. J. Inf. Educ. Technol., vol. 1, no. 4, pp. 298-302, 2011. 